Chapter 5

\title{
Alterations in the Immune Response, Apoptosis and Synaptic Plasticity in Posttraumatic Stress Disorder: Molecular Indicators and Relation to Clinical Symptoms
}

\author{
Anna Boyajyan, Gohar Mkrtchyan, \\ Lilit Hovhannisyan and Diana Avetyan \\ Additional information is available at the end of the chapter \\ http://dx.doi.org/10.5772/52693
}

\section{Introduction}

Posttraumatic stress disorder (PTSD) (ICD-10 codes: F43.1, F62.0; DSM-IV-TR code: 309.81) $[1,2]$ is a complex severe and chronic psychiatric illness influenced by environmental and genetic factors [3-10]. PTSD is an anxiety disorder developed in a person experiencing, witnessing, or learning about an extreme physically or psychologically distressing event, associated with unprecedented violence [11, 12]. Traumatic events that can trigger PTSD include massacres, mass murder scenes, international, civil, political, ethnic and religious wars, genocides, natural and man-made disasters, criminal assaults, serious accidents, terrorist attacks, incarceration, trafficking, rape and other types of sexual assaults [12-17], life threatening illness and the sudden death of a loved one, serious medical illness, injury, surgery, hostage, kidnapping, difficult labors, etc [18-20]. Individuals who experience a trauma of this nature may develop symptoms that fall into three distinct clusters: re-experiencing phenomenon; avoidance and numbing; and autonomic hyperarousal. Symptoms usually begin within the first 3 months after the traumatic event and last for many years, although there may be a delay of months, or even years, before symptoms appear. PTSD patients are characterized by severe emotional state, sharp reduction in adaptive and information receiving abilities. They usually remain out of society, become drug addicted, alcoholic and often commit suicide [21-24]. Degrees of risk to develop PTSD from different traumatic events are presented in table 1.

It was shown that $37 \%$ of Cambodian refugees, $86 \%$ of women refugees in Kabul and Pakistan and $75 \%$ of Bosnian refugee women suffer from PTSD. In USA $60 \%$ of female rape sur- 
vivors and $35 \%$ of UK adult rape victims are affected by PTSD. Similar to adults, some children, who witness or experience traumatic events, develop PTSD. Thus, in the USA $90-100 \%$ of children, who witness a parental homicide or sexual assault, develop PTSD, and in the UK $50 \%$ of sexually abused children are affected by this disorder [25-27].

Equally as staggering are statistics, which monitor the incidence of PTSD among combat veterans. Here, $30 \%$ of the American Vietnam veterans and $56 \%$ of Australia's Vietnam War veterans, $10 \%$ of Desert Storm veterans, 31\% of Australia's Gulf War veterans, $6-11 \%$ of Afghanistan veterans and 12-20\% of Iraq veterans in the US suffer from PTSD [25-28].

Statistical data also demonstrates that women are more than twice as likely to develop PTSD as men. Available data suggests that about $8 \%$ of men and $20 \%$ of women go on to develop PTSD [26, 29-31]. Is was also shown that PTSD is most often developed in representatives of national minorities, people surviving stressful events at list once in their life, as well as in people with low level of education, mental problems, having mentally ill family member or experiencing lack of support from their family members or friends [26, 29-31]. Currently, for about $7-8 \%$ of the USA population, $2-3 \%$ of the UK population, $6.4 \%$ of Australians and $3 \%$ of Cambodians suffer from PTSD [26-28].

\begin{tabular}{cc}
\hline Traumatic event & Degree of risk, \% \\
\hline Rape & 49.0 \\
\hline Other types of sexual violence & 23.7 \\
\hline Physical violence, severe beating & 31.9 \\
\hline Accident and/or serious injuries & $16.8-20.0$ \\
\hline Stabbing, shooting & 15.4 \\
\hline Sudden death of a family member or friend & 14.3 \\
\hline Child's life-threatening illness & 10.4 \\
\hline Murder, death or serious injury witness & 7.3 \\
\hline Natural disasters & $2.0-3.8$ \\
\hline - tsunami & $30.0-50.0$ \\
\hline - earthquake (adults/youths) & $32.0-60.0 / 26.0-95.0$ \\
\hline Man-made disasters & 29.0 \\
\hline Terrorist attacks & 28.0 \\
\hline
\end{tabular}

Table 1. Risk for developing PTSD depending on traumatic event [25-27]

In Armenia PTSD is quite common as well, and is basically found among the descendants of Armenian Genocide victims, including current generation, combatants, refugees and victims of earthquake [32-40]. Thus, according to Goenjian et al, 73\% among 1988 Spitak Earthquake 
survivors developed PTSD 4.5 years after the disaster [36]. In general, 10\% of the world population is suffering from PTSD, and 70\% is under the risk of developing PTSD [26-28].

Patients with PTSD have a reduced quality of life, an increased number of suicides and hospitalizations, high frequency of depressions, alcohol and drug abuse; social, family life and work become impossible.

Molecular mechanisms of generation and development of PTSD and their relation to the clinical psychopathologic criteria of this disorder are not clear yet. The lack of knowledge in this field significantly limits the development of effective therapeutic approaches for treatment of PTSD-affected subjects and prevention of further complications.

\section{Neuroendocrine alterations in PTSD}

PTSD is characterized by the central and autonomic nervous systems hyperarousal that is caused by functional changes in the limbic system, which is located between the brainstem and the cerebral cortex and coordinates their activities. This part of the brain regulates survival behaviors and emotional expression, being primarily concerned with tasks of survival such as eating, sexual reproduction and the instinctive defenses of fight and flight. It also plays a central role in memory processing. The hippocampus and amygdala, parts of the limbic system, regulate learning, memory, and emotion. The amygdala is important for the regulation of emotional memories, particularly for fear causing memories. It has been proven that amygdala is activated in the extreme situations. The hippocampus, on the contrary, is suppressed in these conditions. It has been shown that PTSD is characterized by functional hyperactivity of the amygdala and hypoactivity of the hippocampus [41-43].

A number of data suggests that alterations in the hypothalamic-pituitary-adrenal (HPA) axis and sympathoadrenal system (SAS) play a leading role in PTSD pathogenesis [13, 14, 44]. Thus, PTSD, as compared to norm, is characterized by low cortisol levels in plasma and saliva [45], whereas elevated levels of dehydroepiandrosterone (DHEA) and DHEA-sulfate are detected in this disorder [44-46]. Moreover, increased levels of corticotrophin realizing hormone positively correlated with the high levels of cortisol in cerebrospinal fluid of PTSD patients were observed [47]. Also, PTSD is characterized by increased glucocorticoid receptor sensitivity [48]. An increased levels of noradrenaline, neurotransmitter of central and peripheral sympathetic (adrenergic) nervous system, were detected in the cerebrospinal fluid of PTSD patients [49]. Noradrenaline is considered as one of the important mediators of central and peripheral autonomic stress response and has an important role in the regulation process of emotional memory [50]. It was also shown that high levels of noradrenalinefof the PTSD of the PTSD in urine positively correlate with the symptoms of PTSD [51]. In addition, the increased levels of dopamine, another mediator of the sympathetic nervous system and precursor of noradrenaline, were found in the blood and body fluids of PTSD-affected subjects [51-53].

There are several data indicating assumption that functional abnormalities in neuroendocrine system detected in PTSD patients are conditioned by hereditary factors [54]. Thus, as it 
follows from table 2, PTSD is associated with the genetic mutations in a number of genes encoding neurotransmitters and hormones, their biosynthesis enzymes, receptors and transporters. Interestingly, 6 of the candidate genes for PTSD showed in the table 1 belong to the dopamine system. A positive association between the risk for development PTSD and TaqIA polymorphism of the dopamine D2 receptor gene was found [55]. Also, positive association was revealed between tandem repeat polymorphism of dopamine transporter gene and PTSD [56] as well as between dopamine D4 transporter gene long allele and severity of PTSD symptoms [57].

The $\gamma$-3 subunit of $\gamma$-aminobutyric acid, another mediator of nervous system, has also been studied in PSTD patients. Patients heterozygous for this gene have a higher probability of developing somatic symptoms of PTSD, sleeping disturbances, fair and depression than homozygous patients [58]. The studies of serotonin transporter gene showed that PTSD patients carrying one or two short alleles of this gene have a higher level of depression and suicide compared to carriers of long allele, which has more transcriptional power [59, 60]. The association of the serotonin transporter repeat polymorphism with PTSD was also described [61-63]. Interestingly, recent study of 200 individuals from 12 multigenerational families survived 1998 Spitak earthquake in Armenia demonstrated that PTSD is developing in those individuals, who carry mutations of tryptophan hydroxylase 1 and 2, the rate-limiting enzyme of serotonin biosynthesis [64].

\begin{tabular}{ccc}
\hline Candidate gene & Chromosomal mapping & Source \\
\hline Dopamine D2 receptor & $11 q 23$ & {$[22,55,65]$} \\
\hline Dopamine D4 receptor & $11 p 15.5$ & {$[57]$} \\
\hline Dopamine transporter type 1 & $5 p 15.3$ & {$[56,66]$} \\
\hline Serotonin transporter & $17 q 11$ & {$[68]$} \\
\hline Serotonin type-2A receptor & $13 q 14-q 21$ & {$[72]$} \\
\hline Brain-derived neurotrophic factor & $11 p 13,63,67-71]$ \\
\hline Neuropeptide Y & $7 p 15.1$ & {$[73]$} \\
\hline Glucocorticoid receptor & $5 q 31.3$ & {$[74]$} \\
\hline Dopamine beta-hydroxylase & $9 q 34$ & {$[76]$} \\
\hline Cannabinoid receptor & $6 q 14-q 15$ & {$[77]$} \\
\hline Tryptophan hydroxylase 2 & $4 p 12$ & {$[78]$} \\
\hline Catechol-O-methyltransferase & $22 q 11$ & {$[64]$} \\
\hline
\end{tabular}

Table 2. PTSD-related changes in the neuroendocrine system 


\section{Immune system alterations in PTSD}

Promising studies suggest the involvement of alterations in the immune status [48, 79-86], particularly low-grade inflammatory reactions, in the pathogenesis of PTSD [87-97]. Thus, PTSD patients are characterized by hyperactivation of lymphocytes [80] and increased levels of lipopolysaccharide (LPS)-stimulated expression of interleukin (IL)-6, tumor necrosis factor (TNF)- $\alpha$, and interferon (IFN)- $\gamma$ in immunocompetent cells [81, 82]. Segman et al detected over-expression of immune response-related genes in monocytes of PTSD-affected subjects [85]. Also, in chronic PTSD patients, as compared to norm, a decreased number of T-killer cells $\left(\mathrm{CD}^{+}\right)[98,99]$ and an increase number of T-helper cells $\left(\mathrm{CD} 4^{+}\right)[98,100]$ has been shown, whereas in PTSD patients immediately after a traumatic event a decreased number of T-helper cells was detected [99]. A number of experimental data indicates that natural killer cells' cytotoxicity in PTSD is lower than in norm [97, 99, 101-104], while the total number or these cells, as well as a number of $\mathrm{CD}_{16}{ }^{+}$and $\mathrm{CD} 56^{+}$cells in their total population is higher than in norm [99, 104]. At the same time some studies show that natural killer cells' cytotoxicity in PTSD patients is higher than in healthy subjects $[105,106]$. The analysis of the above mentioned data revealed altered cell-mediated immunity in PTSD patients and demonstrates that depending on traumatic event, duration and stage of the illness, these alterations may be either under- or over-represented [97, 107].

\subsection{Cytokine network in PTSD}

A number of studies have demonstrated changes in a functional state of cytokines and their receptors, important mediators and regulators of the immune response in PTSD-affected subjects. Here the increased blood levels of proinflammatory cytokines (e.g. IL-1 $\beta$, IL-6, TNF- $\alpha$, INF- $\gamma$ ) and decreased levels of anti-inflammatory cytokines (e.g. IL-4) are detected in chronic PTSD patients indicating the involvement of low-grade systemic inflammatory reactions in PTSD pathogenesis (table 3).

In our own study the levels of proinflammatory and chemotactic cytokines IL-1 $\beta$, IL-6, TNF$\alpha$, IL- 8 and MCP- 1 in the blood serum of chronic PTSD patients (combat veterans) and ageand sex-matched healthy subjects (HS; a control group) were determined using enzymelinked immunosorbent assay (ELISA). Assessment of possible correlation of the above mentioned parameters with each other and with the expression of PTSD clinical symptoms was also performed. The latest were evaluated using Structured Clinical Interview for the DSM-IV Axis I Disorders (SCID PTSD module) [112] and Clinician-Administered PTSD Scale (CAPS) [113]. In particular, we assessed correlation between the levels of cytokines and the degree of expression of such PTSD clinical symptoms as persistent re-experiencing of the traumatic event (B cluster), persistent avoidance of stimuli associated with the trauma and emotional numbing (C cluster); persistent symptoms of increasing arousal (D cluster) [2]. In table 4 brief descriptions of the study groups is given. Table 5 demonstrates the individual symptom clusters (B, C, and D criteria), and total CAPS scores of PTSD-affected subjects involved in our study. 


\begin{tabular}{|c|c|c|}
\hline Chronic PTSD patients: group description & $\begin{array}{l}\text { Changes in the blood levels of cytokines } \\
\text { as compared to norm* }\end{array}$ & Source \\
\hline Accidents survivors ( $n=13$ ) & $\uparrow I L-1 \beta, \uparrow I L-6, \uparrow T N F-a$ & [89] \\
\hline Accident survivors $(n=86)$ & $\uparrow I L-1 \beta$ & [46] \\
\hline Accidents survivors $(n=14)$ & $\uparrow I L-1 \beta, \uparrow T N F-\alpha, \downarrow I L-4$ & [93] \\
\hline Bosnian refugees $(n=12)$ & $\uparrow I L-6$ & [108] \\
\hline Combat veterans $(n=19)$ & $\uparrow I L-1 \beta, \uparrow I L-6, \uparrow T N F-a$ & [87] \\
\hline Combat veterans $(n=11)$ & $\uparrow I L-6, \uparrow T N F-a$ & [91] \\
\hline Individuals abused in childhood $(\mathrm{n}=30)$ & $\uparrow I N F-\gamma$ & [109] \\
\hline Individuals abused in childhood $(n=177)$ & $\uparrow T N F-a ， \downarrow I L-4$ & [110] \\
\hline $\begin{array}{l}\text { Individuals exposed to different traumatic events } \\
\qquad(\mathrm{n}=60)\end{array}$ & $\downarrow \mid \mathrm{IL}-4$ & [97] \\
\hline $\begin{array}{l}\text { Individuals exposed to intimate partner violence } \\
\qquad(\mathrm{n}=62)\end{array}$ & $\uparrow I L-6, \uparrow T N F-a, \uparrow I N F-\gamma$ & [111] \\
\hline
\end{tabular}

Table 3. Changes in the blood levels of some cytokines in chronic PTSD patients

Data statistics include nonparametric Mann-Whitney U-test and correlation analysis with calculation of Spearman's rank correlation coefficient (Rs). Parts of this study have been published [114, 115].

The results obtained indicated that PTSD, as compared to norm, is characterized by increased levels of the mentioned above cytokines (Table 6), which is consistent with reports by other research groups (Table 3) [46, 87, 89, 91, 93, 108, 110, 111].

A significant correlation between the levels of IL-1 $\beta$ and IL-6 (Rs=0.45; $<<0.003$ ), as well as between IL-1 $\beta$ and MCP-1 (Rs=0.3; $<<0.03$ ) in PTSD patients was revealed, whereas no significant correlation between the levels of cytokines was observed in control group. Also, a significant positive correlation of IL-1 $\beta$ and IL-6 blood levels with PTSD symptoms within B, $\mathrm{C}$ and D criteria (CAPS scores) was detected. Thus, levels of IL-1 $\beta$ positively correlated with $\mathrm{B}$ frequency $(\mathrm{Rs}=0.004, \mathrm{p}=0.007), \mathrm{C}$ frequency, intensity, and frequency + intensity $(\mathrm{Rs}=0.4$, $\mathrm{p}=0.009$; Rs $=0.30, \mathrm{p}=0.035, \mathrm{r}=0.36, \mathrm{p}<0.02$, respectively), frequency of $\mathrm{B}, \mathrm{C}$ and $\mathrm{D}$ (Rs $=0.37$, $\mathrm{p}<0.02)$, total intensity of $B, C$ and $D(R s=0.3, p<0.048)$ and total frequency + intensity of $B, C$ and $\mathrm{D}(\mathrm{Rs}=0.3, \mathrm{p}<0.03)$. Blood levels of IL-6 positively correlated with cluster $\mathrm{B}$ frequency (Rs=0.3, p=0.048).

Our data provides further evidence on the association of chronic inflammation with PTSD and clearly demonstrates the interrelation between the expression of PTSD symptoms and inflammatory reactions. Alterations in the immune response in PTSD accompanied by lowgrade systemic inflammation aggravate disease course and severity and contribute to development of complications. Thus, PTSD is often associated with autoimmune and 
inflammatory disorders such as rheumatoid arthritis, psoriasis and inflammatory bowel disease. Patients with PTSD are at a higher risk for diabetes mellitus and cardiovascular diseases (atherosclerosis, myocardial infarction) [116-123]. It is interesting that in peridontitis patients with PTSD higher expression of inflammatory processes was obtained than in those peridontitis patients, who were not affected by PTSD [88].

\begin{tabular}{ccc}
\hline Study group & PTSD & HS \\
\hline Total number (male/female) & $120(116 / 4)$ & $80(76 / 4)$ \\
\hline Mean age $(\mathrm{M} \pm \mathrm{SD})$ & $42 \pm 11.3$ & $39 \pm 9.1$ \\
\hline$[\text { Cortisol }]^{*}(\mathrm{M} \pm \mathrm{SD}), \mathrm{ng} / \mathrm{ml}$ & $124 \pm 47$ & $145 \pm 55$ \\
\hline$[\mathrm{DHEA}]^{*}(\mathrm{M} \pm \mathrm{SD}), \mathrm{ng} / \mathrm{ml}$ & $13 \pm 7$ & $10 \pm 5$ \\
\hline$[\text { DHEA-sulfate }]^{*}(\mathrm{M} \pm \mathrm{SD}), \mu \mathrm{gg} / \mathrm{ml}$ & $1.8 \pm 0.9$ & \\
\hline *- measured in the blood serum & & \\
\hline
\end{tabular}

Table 4. Brief description of the study groups

\begin{tabular}{ccc}
\hline Symptom clusters & Parameters & PTSD patients scores \\
\hline B cluster & Frequency (0-20) & $11.8 \pm 3.98$ \\
\cline { 2 - 3 } & Intensity (0-20) & $11.6 \pm 3.46$ \\
\cline { 2 - 3 } C cluster & Frequency + Intensity (0-40) & $23.4 \pm 7.02$ \\
\cline { 2 - 3 } & Frequency (0-28) & $16.4 \pm 5.10$ \\
\hline & Intensity (0-28) & $14.8 \pm 4.96$ \\
\hline D cluster & Frequency + Intensity (0-56) & $31.2 \pm 9.85$ \\
\cline { 2 - 3 } & Intensity (0-20) & $13.5 \pm 3.07$ \\
\cline { 2 - 3 } & Frequency + Intensity (0-40) & $12.2 \pm 2.52$ \\
\hline B+C+D (Total) & Frequency (0-68) & $25.7 \pm 5.30$ \\
\cline { 2 - 3 } & Frequency + Intensity (0-136) & $41.7 \pm 9.85$ \\
\hline & Intensity (0-68) & $38.6 \pm 9.18$ \\
\hline & & $80.3 \pm 18.50$ \\
\hline
\end{tabular}

Table 5. The individual symptom clusters (B, C, and D criteria), total and overall CAPS scores (M \pm SD) of PTSD-affected subjects (Score ranges are indicated in parenthesis) 


\begin{tabular}{|c|c|c|c|}
\hline Study group & Cytokine & Level ( $M \pm S D), \mathrm{pg} / \mathrm{ml}$ & $P=$ \\
\hline PTSD & \multirow{2}{*}{ IL-1 $\beta$} & $8.2 \pm 1.0$ & \multirow{2}{*}{0.002} \\
\hline $\mathrm{HS}$ & & $5.1 \pm 0.7$ & \\
\hline PTSD & \multirow{2}{*}{ IL-6 } & $19.0 \pm 2.5$ & \multirow{2}{*}{0.025} \\
\hline $\mathrm{HS}$ & & $16.0 \pm 2.3$ & \\
\hline PTSD & \multirow{2}{*}{ TNF-a } & $12.0 \pm 1.6$ & \multirow{2}{*}{0.049} \\
\hline $\mathrm{HS}$ & & $10.8 \pm 1.4$ & \\
\hline PTSD & \multirow{2}{*}{ IL-8 } & $11.5 \pm 1.5$ & \multirow{2}{*}{0.022} \\
\hline HS & & $10.1 \pm 1.3$ & \\
\hline PTSD & \multirow{2}{*}{$\mathrm{MCP}-1$} & $223.3 \pm 30.6$ & \multirow{2}{*}{0.030} \\
\hline HS & & $187.2 \pm 25.5$ & \\
\hline
\end{tabular}

Table 6. Comparative analysis of the blood serum levels of proinflammatory and chemotactic cytokines in patients with PTSD and HS

The pathological mechanisms of the development of inflammatory reactions in PTSD are not clear. However, it is obvious that neuroendocrine and immune impairments in PTSD are interrelated. It is well-established fact that the immune system functional activity is regulated by neurotransmitters and hormones, particularly those related to HPA axis and SAS. On the other hand, immune system mediators and their receptors on the immunocompetent cells may regulate the neuroendocrine system. In normal physiological conditions the immune, endocrine and nervous systems maintain homeostasis by controlling each other, thus developing adequate stress response [79, 124]. Changes in neuro-endocrine-immune interactions (influenced by either environmental or genetic factors) may result to abnormal response to stress and generation of PTSD. On the other hand, the action of cytokines, mediators of inflammation, is tightly coupled with physiological and pathophysiological reactions of the organism, and their important role is to coordinate the efforts of the immune, endocrine and nervous systems during the stress response [125-128]. This may represent one of the possible mechanisms responsible for increased cytokines levels and development of chronic inflammatory reactions in PTSD, the disease characterized by neuroimmune and endocrine alterations $[82,86,129]$. It connection with this it has to be also mentioned that a number of recent clinical and experimental data suggests the implication of low-grade systemic inflammatory reactions accompanied by increase in cytokines levels in pathogenesis of many psychiatric disorders [130-132].

\subsection{The complement system in PTSD}

The complement system is major effector of the immune response, which acts on the interface of innate and adaptive immunity, and is a key component and trigger of many immunoregulatory mechanisms. Activation of the complement generates opsonins, anaphylatoxins, and chemotaxins, mediators of inflammation and apoptosis (Figure 1) 
[133-135]. Changes in the functional activity of the complement cascade contribute to the pathology of many human diseases [136-138], including mental disorders [139-144], and are also detected during physiological stress [145-146]. The alterations in the complement cascade have been considered as indicator of the implication of inflammatory component in disease etiology, pathogenesis and/or progression [136-138].

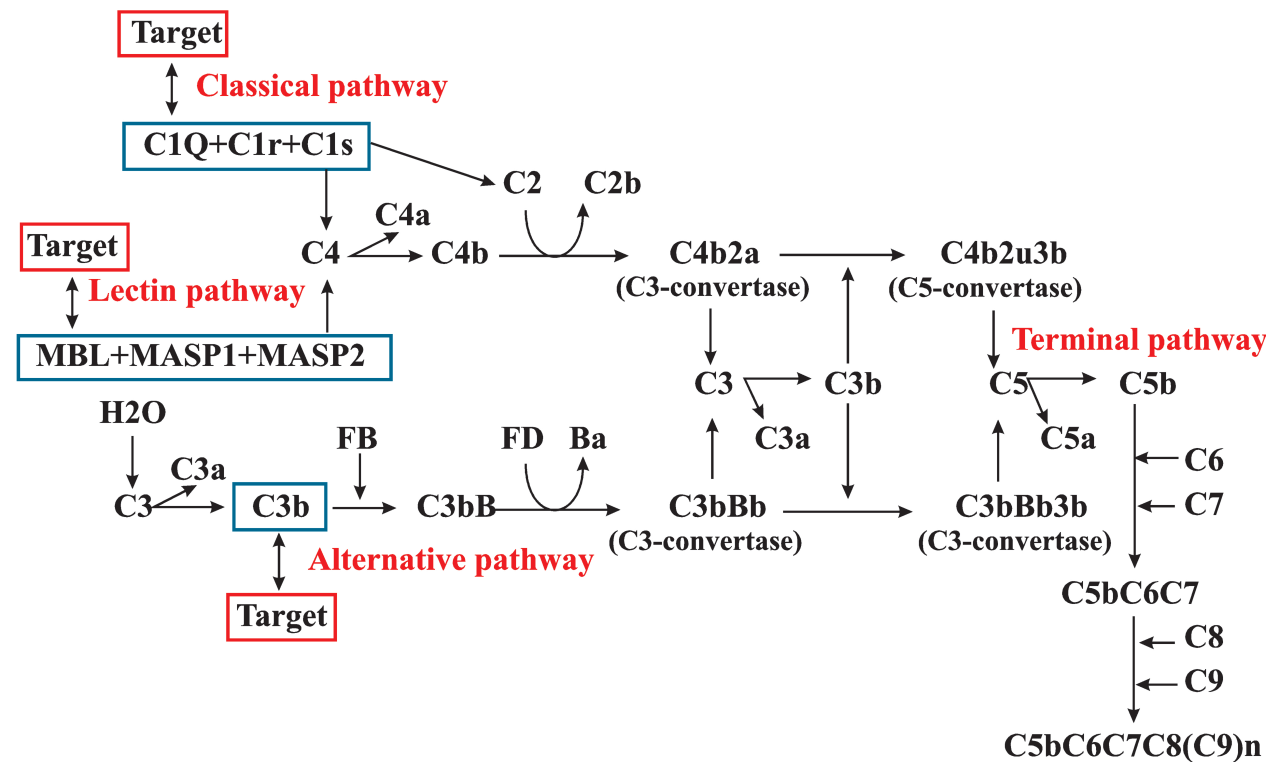

(MAC)

Figure 1. Complement activation pathways; $\mathrm{C} 1 \mathrm{Q}, \mathrm{C} 1 \mathrm{r}, \mathrm{C} 1 \mathrm{~s}$ - subunits of the complement $\mathrm{C} 1$ component; $\mathrm{MBL}$ - mannan-binding lectin; MASP1 - MBL-associated serine peptidase 1; MASP2 - MBL-associated serine peptidase 2; FD - factor D; FB - factor B; MAC - membrane attack complex.

The complement system with its central position in innate and adaptive immunity mediates a variety of effector functions. It consists of more than 30 circulating proteins, cell surface receptor and regulator proteins. It is a complex cascade involving proteolytic cleavage of serum glycoproteins often activated by cell receptors. This cascade ultimately results in induction of the antibody responses, inflammation, phagocyte chemotaxis, and opsonization of apoptotic and necrotic cells, facilitating their recognition, clearance, and lysis. Complement exhibits three activation pathways - classical, alternative, and lectin, initiated via separate mechanisms, and a single terminal pathway that results in a formation of the membrane attack complex (Figure 1) and subsequent cell lysis [133-135]. During the past decades it has become evident that dysfunction of complement contributes to the pathology of many human diseases [136-138], including mental disorders (schizophrenia, Alzheimer's disease, Huntington's and Pick's diseases) [139-142], and is also detected during physiological stress [145-146]. While, as it was already mentioned, PTSD-affected subjects showed a low-grade 
systemic proinflammatory state, the complement system in PTSD has been never studied before.

In our study we assessed the functional activity of the complement cascade in PTSD by determining total hemolytic activities of its classical and alternative pathways, and hemolytic activities of its individual components, C1, C2, C3, C4, factor B and factor D, in the blood serum of chronic PTSD patients (combat veterans) and HS (tables 4, 5). C1, C2 and C4 are main components of the classical pathway, factor $\mathrm{B}$ and factor $\mathrm{D}$ are essential components of the alternative pathway, and C3 is the initial point for the alternative pathway and a converge point of all three complement activation pathways, starting up for the terminal pathway (Figure 1) [133-135]. In addition, correlation study between all measured parameters was also performed. Hemolytic activities of the complement classical and alternative pathways (CH50 and AH50, respectively) and of the complement components $\mathrm{C} 1$ (C1H50), C2 (C2H50), C3 (C3H50), C4 (C4H50), factor B (fBH50), and factor D (fDH50) in the blood serum of PTSD-affected and healthy subjects were measured by application of the earlier developed methods $[147,148]$. Data was analyzed by Student's unpaired two-tailed t-test and Pearson's correlation analysis including calculation of relevant correlation coefficient (r). Parts of this study have been published [149-152].

The results obtained are presented in table 7 . According to the results obtained, mean values of serum $\mathrm{CH} 50, \mathrm{C} 1 \mathrm{H} 50, \mathrm{C} 2 \mathrm{H} 50$ and $\mathrm{C} 4 \mathrm{H} 50$ in PTSD patients were significantly 2.1, 1.34, 1.2 and 1.6 times significantly higher than in case of $\mathrm{HS}(\mathrm{p}<0.05)$. On the contrary, mean values of serum $\mathrm{C} 3 \mathrm{H} 50, \mathrm{AH} 50, \mathrm{fBH} 50$, and $\mathrm{fDH} 50$ in PTSD patients were 1.5, 1.7, 1.6, and 2.3 times significantly lower as compared to HS $(\mathrm{p}<0.05)$. Correlation analysis also demonstrated that in PTSD affected subjects C1H50 is significantly correlated with C2H50 ( $\mathrm{r}=-0.375, \mathrm{p}<0.04)$, $\mathrm{C} 3 \mathrm{H} 50$ is significantly correlated with $\mathrm{C} 1 \mathrm{H} 50, \mathrm{C} 2 \mathrm{H} 50$ and $\mathrm{C} 4 \mathrm{H} 50$ and $\mathrm{AH} 50$ ( $\mathrm{r}=0.53, \mathrm{p}<0.037$; $\mathrm{r}=0.72, \mathrm{p}=0.002 ; \mathrm{r}=0.5, \mathrm{p}=0.05 ; \mathrm{r}=0.57, \mathrm{p}=0.027$, respectively). No significant correlation between the above-mentioned parameters was detected in the HS group $(p>0.05)$.

\begin{tabular}{|c|c|c|c|}
\hline Hemolytic activity, U/ml* & PTSD $(M \pm S D)$ & $H S(M \pm S D)$ & $P=$ \\
\hline $\mathrm{CH} 50$ & $375.00 \pm 164.40$ & $176.00 \pm 88.50$ & 0.0002 \\
\hline $\mathrm{C} 1 \mathrm{H} 50$ & $92.21 \pm 52.83$ & $68.80 \pm 37.39$ & 0.0400 \\
\hline $\mathrm{C} 2 \mathrm{H} 50$ & $67.60 \pm 35.10$ & $58.80 \pm 8.80$ & 0.0450 \\
\hline $\mathrm{C} 3 \mathrm{H} 50$ & $37.57 \pm 16.26$ & $55.92 \pm 28.60$ & 0.0300 \\
\hline $\mathrm{C} 4 \mathrm{H} 50$ & $60.10 \pm 28.42$ & $36.64 \pm 20.31$ & 0.0300 \\
\hline $\mathrm{AH} 50$ & $52.30 \pm 18.17$ & $87.60 \pm 9.80$ & 0.0001 \\
\hline $\mathrm{fBH} 50$ & $40.80 \pm 14.30$ & $65.2 \pm 34.1$ & 0.0200 \\
\hline fBH50 & $71.70 \pm 15.98$ & $163.70 \pm 70.58$ & 0.0010 \\
\hline
\end{tabular}

Table 7. Functional state of the complement system in PTSD patients and HS 
The results obtained in our study clearly demonstrated that pathogenesis of PTSD is characterized by complement dysfunction including hyperactivation state of the complement classical pathway and hypoactivation state of the complement alternative pathway. The alternative pathway of complement is activated following spontaneous hydrolysis of the thioester bond of native C3, resulting into binding of factor B, which is cleaved by factor D, generating the efficient alternative pathway $\mathrm{C} 3$ convertase $\mathrm{C} 3 \mathrm{bBb}$. Multifunctional complement protein $\mathrm{C} 3$ is the initial point of the alternative pathway, and, at the same time, a converge point of all three complement activation pathways, i.e. starting point for the terminal pathway [93, 135, 153]. Hypoactivation state of the alternative pathway together with decreased activity of the complement C3 component, detected in PTSD affected subjects, probably reflects depletion of the $\mathrm{C} 3$ component due to its overutilization through the terminal pathway. This suggestion is convenient with correlation data indicating positive correlation between $\mathrm{CH} 50$ and $\mathrm{C} 3 \mathrm{H} 50$ and absence of any correlation between $\mathrm{AH} 50$ and $\mathrm{ABH} 50$, and AH50 and fDH50 in PTSD affected subjects. Thus, it is obvious that the alternative pathway in PTSD is suppressed on the initial stage of its activation, and that PTSD is also characterized by overactivated terminal complement pathway. On the other hand, absence of correlation between $\mathrm{AH} 50$ and $\mathrm{CH} 50$ suggests that alterations in activities of the classical and the alternative complement pathways in PTSD are not interdependent.

As it was mentioned above, alterations in the complement cascade have been considered as indicator of the implication of inflammatory component in disease etiology, pathogenesis and/or progression [136-138]. Our study demonstrates that PTSD is associated with dysfunction of the complement system, and reveals the altered chains of the complement cascade. The results obtained provide further evidence on the involvement of the inflammatory component in pathogenesis of PTSD. Here we hypothesize that neuroendocrine mechanisms related to PTSD modulating the immune function might affect the initial steps in the inflammatory cascade and thus influence alterations in the functional activity of the major mediator of the inflammatory response, the complement system. However, to address molecular mechanisms responsible for the complement dysfunction in PTSD as well as their role in PTSD pathogenesis further studies are needed.

\subsection{Immune complexes in PTSD}

Formation of immune complexes (IC) is a normal physiological reaction of organism to foreign or autoantigen. IC may interact with both humoral and cellular components of the immune recognition system, activate the complement cascade, and thus affect the immune response on multiple levels [154-156]. In healthy conditions IC are easily eliminating from circulation through complement deposition, followed by their opsonization, phagocytosis, and further processing by proteases [154, 156-158]. In pathologic conditions inappropriate clearance or deposition of IC result in increased levels of IC in circulation. Circulating IC may deposit in endothelial or vascular structures provoking prolonged inflammatory response by permanent activation of the complement cascade through the classical pathway, generation of cytotoxic agents and tissue damage [159-163]. Deposition of IC is a prominent feature of many diseases [162-164] including those characterized by low-grade systemic in- 
flammation, such as schizophrenia [144], diabetes mellitus [165, 166], ischemic and hemorrhagic stroke [167-169].

In our own study we, for the first time, determined total levels of IC as well as the levels of IC containing activation products of the complement system, C1q- and C3d-IC, in the blood serum of chronic PTSD patients (combat veterans) and HS. Brief characteristic of study groups is given in tables 3,4 . Total levels of IC were measured by a previously published spectrophotometric method and expressed in absorbency units at $280 \mathrm{~nm}\left(\mathrm{~A}_{280}\right)$ [167]; C1qand C3d-IC were measured by ELISA. Data was analyzed by Student's unpaired two-tailed t-test and Pearson's correlation analysis including calculation of relevant correlation coefficient (r). Parts of this study have been published [149, 150, 170].

According to the results obtained, PTSD-patients comparing to HS are characterized by significantly increased serum levels of total IC as well as C1q- and C3d-IC. Thus, the mean level of total IC in PTSD patients was 1.5 times higher than in HS ( $p=0.0055)$ and the levels of C1q-IC, and C3d-IC were 1.7 ( $\mathrm{p}=0.024)$ and 1.6 times $(\mathrm{p}=0.0004)$, respectively, higher as compared to HS. The results obtained are summarized in table 8.

\begin{tabular}{cccc}
\hline$[I C],(M \pm S D)$ & P $=$ \\
\cline { 2 - 3 } & \multicolumn{2}{c}{ Study group } & \\
\hline$\left[\right.$ Total IC], $\mathrm{A}_{280}$ & $0.18 \pm 0.1$ & $0.12 \pm 0.03$ & 0.0055 \\
\hline$[\mathrm{C} 1 \mathrm{q}-\mathrm{IC}], \mu \mathrm{g} / \mathrm{ml}(\mathrm{M} \pm \mathrm{SD})$ & $44.6 \pm 37.67$ & $26.28 \pm 16.33$ & 0.024 \\
\hline$[\mathrm{C} 3 \mathrm{~d}-\mathrm{IC}], \mu \mathrm{g} / \mathrm{ml}(\mathrm{M} \pm \mathrm{SD})$ & $29.75 \pm 21.91$ & $18.67 \pm 8.22$ & 0.0004 \\
\hline
\end{tabular}

Table 8. Serum levels of the total IC, C1q-IC and C3d-IC in PTSD patients and HS

In addition, a significant positive correlation between the levels of C1q- and C3d-IC ( $\mathrm{r}=0.32$; $\mathrm{p}<0.03)$ was detected in PTSD patients affected subjects. Moreover, in patients with PTSD we also revealed a significant positive correlation between the total levels of IC and hemolytic activity of the classical complement pathway. This finding indicates that increased total levels of IC in circulation may be responsible for hyperactivation of the classical complement cascade detected in PTSD [149-152, 170].

The increased blood levels of C1q-IC in PTSD provide further evidence for this suggestion. $\mathrm{C} 1 \mathrm{q}-\mathrm{IC}$ contain $\mathrm{C} 1 \mathrm{q}$ subunit of the complement protein $\mathrm{C} 1$, and binding of IC to $\mathrm{C} 1 \mathrm{q}$ initiates activation of the classical complement cascade (Figure 1) [133-135].

C3d-IC contain activation cleavage products of the complement C3 protein, opsonins C3b, $\mathrm{iC} 3 \mathrm{~b}$ and $\mathrm{C} 3 \mathrm{dg}$. These entire products contain "d"-terminal fragment of the C3 polypeptide chain. In healthy conditions C3d-IC are eliminated from the blood through interaction with the complement receptors on monocytes, neutrophils and erythrocytes. Monocytes and neutrophils subject C3d-IC to phagocytosis, and erythrocytes transfer them to liver and spleen for further phagocytosis by macrophages. Increased blood levels of C3d-IC suggest about al- 
terations in mechanisms responsible for their recognition and clearance by the above mentioned cells. High levels of C3d-IC result in hyper-production of antibodies, because binding of C3d-IC to type-2 complement receptors (CR2) on the surface of B-lymphocytes induces the production of immunoglobulins by these cells [154, 156-158]. Therefore, our results indicate that PTSD is characterized by altered mechanisms of IC recognition and clearance, which may be responsible for the increased classical pathway functional activity, chronic activation of the immune system and systemic inflammation.

\subsection{Interrelation between inflammatory response, apoptosis and synaptic plasticity in PTSD}

As it was already mentioned, the molecular pathomechanisms responsible for development of inflammatory reactions in PTSD are yet unclear, which limits the progress in development of the efficient measures of PTSD rehabilitation therapy and prevention of its complications. On the other hand, it is known that apoptosis plays an important role in downregulation of the inflammatory response by reducing the lifespan of activated immunocompetent cells [171-173]. Therefore, we proposed that one of the factors contributing to PTSD-associated inflammation may be apoptotic dysfunction as it was observed in case of other disorders like familial Mediterranean fever [174], inflammatory bowel disease [175], systemic inflammatory response syndrome [176], pulmonary hemorrhage or endotoxemia [177], etc.

On the third though, apoptosis is considered as the important regulator of synaptic plasticity. Apoptotic alterations have a significant input in synaptic dysfunction and lead to changes in structural and functional integrity of neuronal circuits [178-180]. Therefore, apoptosis may be also responsible for altered synaptic plasticity in PTSD [181] resulting in cognitive impairments and development of depressions in PTSD affected subjects [182-184].

To check our hypotheses, in the blood serum of patients with PTSD, in comparison to HS the levels of marker proteins for apoptosis and synaptic plasticity, annexin-A5 [185] and complexin-2 [186], respectively, and the inflammatory marker, TNF- $\alpha$, were determined by ELISA. The analysis of correlation between these parameters was performed. Brief characteristic of study groups is given in tables 4, 5. Data statistics include nonparametric MannWhitney U-test and correlation analysis with calculation of Spearman's rank correlation coefficient (Rs). The results presented below have not been published yet.

According to the results obtained, the levels of both annexin-A5 and complexin-2 in PTSD patients were significantly $2.34(\mathrm{p}=0.0001)$ and $1.21(\mathrm{p}=0.03)$ times, respectively, lower than in case of HS (table 9). In addition, a significant positive correlation between the levels of annexin-A5 and complexin-2 ( $\mathrm{Rs}=0.38, \mathrm{p}=0.045)$, on the one hand, and a significant negative correlation between the levels of annexin-A5 and the increased levels of TNF- $\alpha$ (Rs $=-0.35$, $\mathrm{p}=0.047$ ), on the other hand, were detected in PTSD.

No statistical significant correlation was observed between these parameters in case of HS. 


\begin{tabular}{ccccc}
\hline Study group & [Annexin-A5], ng/ml & $\mathbf{P}=$ & [Complexin-2], pg/ml & $\mathbf{P}=$ \\
\hline \multirow{2}{*}{ PTSD } & $0.82 \pm 0.70$ & \multirow{2}{*}{0.0001} & $121.5 \pm 41.20$ & 0.03 \\
\cline { 1 - 3 } HS & $1.92 \pm 1.05$ & & $146.9 \pm 56.64$ & \\
\hline
\end{tabular}

Table 9. The levels of annexin A5 and complexin-2 $(M \pm S D)$ in PTSD patients and HS

Our results demonstrated that PTSD is characterized by the decreased blood levels of the apoptotic marker circulating annexin A5 indicating association of apoptosis hypofunction with this disorder.

On the base of the results obtained we suggest that PTSD is characterized by low rate of apoptosis associated with the defects in synaptic plasticity and that anomalous apoptosis may also represent one of the factors responsible for development of PTSD-associated chronic inflammation. This suggestion is confirmed by recent findings indicating the increased levels of leukocytes in the blood of chronic PTSD patients [48, 93, 94].

\section{Conclusion}

The results presented in this chapter provide evidence on implication of altered immune response, particularly low-grade systemic inflammation, in pathogenesis of PTSD.

In particular, we demonstrated that chronic PTSD is characterized by increased blood levels of proinflammatory and chemotactic cytokines, IL- $1 \beta$, IL-6, TNF- $\alpha$ and MCP-1, IL-8, respectively. Here, the increased levels of IL- $1 \beta$ and IL- 6 positively correlate with the degree of expression of clinically significant symptoms of this disease, which indicate that these cytokines may be considered as new therapeutic targets for PTSD treatment. In addition, we demonstrated that chronic PTSD is characterized by altered mechanisms of IC recognition and clearance resulting in the increased levels of total IC, as well as C1q-IC and C3d-IC in circulation. Furthermore, our results showed that chronic PTSD is characterized by alterations in functional activity of the complement pathways including hyperactivation state of the classical and terminal pathways, hypoactivation state of the alternative pathway and deficiency of the $\mathrm{C} 3$ complement protein. Here, the data obtained suggests that hyperactivation of the classical complement pathway is induced by the increased levels of IC, particularly $\mathrm{C} 1 \mathrm{q}-\mathrm{IC}$, in circulation. Regarding the alternative pathway, our results clearly demonstrated that it is suppressed at the initial stage of activation and that decreased activity of this pathway in PTSD is stipulated by decreased activities of its components, factor B and factor $\mathrm{D}$, and deficiency of the protein $\mathrm{C} 3$, a key component of the complement cascade.

In summery, we concluded that changes in functional activities of the proinflammatory and chemotactic cytokines and complement cascade, as well as disturbances in the IC recognition and clearance processes are implicated in pathogenesis of chronic PTSD.

Another important conclusion that can be drawn from the results of our study is that pathogenesis of chronic PTSD is characterized by low rate of apoptosis associated with the defects 
in synaptic plasticity, and that anomalous apoptosis may represent one of the factors responsible for development of PTSD-associated chronic inflammation.

\section{Author details}

Anna Boyajyan, Gohar Mkrtchyan, Lilit Hovhannisyan and Diana Avetyan

*Address all correspondence to: aboyajyan@sci.am

Institute of Molecular Biology, National Academy of Sciences, Yerevan, Republic of Armenia

\section{References}

[1] ICD-10. International statistical classification of diseases and related health problems (Edition: 10). Geneva: World Health Organization; 1992.

[2] DSM-IV-TR. Diagnostic and statistical manual of mental disorders by the American Psychiatric Association (edition 4, text revised). USA: Amer. Psych. Pub; 2000.

[3] Segman RH, Shalev AY. Genetics of posttraumatic stress disorder. CNS Spectr 2003;8(9): 693-698.

[4] Eley TC, Sugden K, Corsico A, Gregory AM, Sham P. Gene-environment interaction analysis of serotonin system markers with adolescent depression. Mol Psychiatry 2004;9(10): 908-915.

[5] Grabe HJ, Lange M, Wolff B, Völzke H, Lucht M. Mental and physical distress is modulated by a polymorphism in the 5-HT transporter gene interacting with social stressors and chronic disease burden. Mol Psychiatry 2005;10(2): 220-224.

[6] Koenen KC. Genetics of posttraumatic stress disorder: review and recommendations for future studies. J Trauma Stress 2007;20: 737-750.

[7] Binder EB, Bradley RG, Liu W, Epstein MP, Deveau TC, Mercer KB, Tang Y, Gillespie CF, Heim CM, Nemeroff CB, Schwartz AC, Cubells JF, Ressler KJ. Association of FKBP5 polymorphisms and childhood abuse with risk of posttraumatic stress disorder symptoms in adults. JAMA 2008; 299(11) 1291-1305.

[8] Amstadter AB, Nugent NR, Koenen KC. Genetics of PTSD: fear conditioning as a model for future research. Psych Ann 2009;39: 358-367.

[9] Koenen KC, Aiello AE, Bakshis E, Amstadter AB, Ruggiero KJ, Acierno R, Kilpatrick DG, Gelernter J, Galea S. Modification of the association between serotonin transporter genotype and risk of posttraumatic stress disorder in adults by county-level social environment. Am J Epidemiol 2009;169: 704-711. 
[10] Mellman TA, Alim T, Brown DD, Gorodetsky E, Buzas B, Lawson WB, Goldman D, Charney DS. Serotonin polymorphisms and posttraumatic stress disorder in a trauma exposed African American population. Depress Anxiety 2009;26: 993-997.

[11] Shalev AY, Peri T, Orr SP, Bonne O, Pitman RK. Auditory startle responses in help seeking trauma survivors. Psych Res 1997;69: 1-7.

[12] Dietrich AM. As the pendulum swings: The etiology of PTSD, complex PTSD, and revictimization. Traumatology 2000;6: 41-59.

[13] Yehuda R, Giller EL, Levengood RA, Southwick SM, Siever LJ. Hypotalamic-pituitary-adrenal functioning in post-traumatic stress disorder: expanding the concept of the stress response specrtum. Neurobiologial and clinical consequences of stress: from normal adaptation to post-traumatic stress disorder. Hagerstown. MD: Lippincott-Raven; 1991. p351-366.

[14] Yehuda R. Biology of posttraumatic stress disorder. J Clin Psychiatry 2001;62(17): 41-46.

[15] Roth S, Newman E, Pelcovitzl D. Complex PTSD in victims exposed to sexual and physical abuse: results from the DSM-IV field trial for posttraumatic stress disorder. J Trauma Stress 1997;10(4): 539-545.

[16] Connor MD, Butterfield MI. Post-traumatic stress disorder. FOCUS 2003;1(3): 247-262.

[17] Kinchin D. Post traumatic stress disorder: the invisible injury. UK: Success Unlimited; 2005.

[18] Beck CT. Birth trauma: in the eye of the beholder. Nurs Res 2004;53(1): 28-35.

[19] Beck CT. Post-traumatic stress disorder due to childbirth: the aftermath. Nurs Res 2004;53(4): 216-224.

[20] Aldecoa C, Pico S, Rico J, Vazquez B, Gomez L, Garcia-Bernardo C, Gomez-Herreras J. Post-traumatic stress disorder after surgical ICU admission. Crit Care 2010;14(1): 441.

[21] Amir M, Kaplan Z, Efroni R, Kotler M. Suicide risk and coping styles in post-traumatic stress disorder patients. Psychother Psychosom 1999;68(2): 76-81.

[22] Young RM, Lawford BR, Noble EP, Kann B, Wilkie A, Ritchie T, Arnold L, Shadforth $\mathrm{S}$. Harmful drinking in military veterans with post-traumatic stress disorder: association with the D2 dopamine receptor A1 allele. Alcohol 2002;37(5): 451-456.

[23] Ben-Ya'acov Y, Amir M. Posttraumatic symptoms and suicide risk. Person Indiv Diff 2004;36: 1257-1264.

[24] Tull M. The Connection Between PTSD and alcohol and drug use. Posttraumatic stress. New York: About.com 2008. http://ptsd.about.com/od/relatedconditions/a/ drugalcohol.htm. 
[25] Picking up the peaces (n.d.). Raising awareness about PTSD. 2012. http://pickingupthepeaces.org.au/post-traumatic-stress-disorder-statistics/ (accessed 25 February 2012).

[26] PTSD alliance (n.d.). About PTSD: statistics. 2012. www.ptsdalliance.org/ about_what.html. (accessed 25 February 2012).

[27] HMForces.co.uk (n.d.). Post traumatic stress disorder - helping family with PTSD. 2012. http://www.hmforces.co.uk/education/articles/593-post-traumatic-stress-disorder-helping-family-with-ptsd. (accessed 25 February 2012).

[28] Creamer MC, Burgess P, McFarlane AC. Post-traumatic stress disorder: findings from the Australian National Survey of Mental Health and Well-being. Psychol Med 2001;31(7): 1237-1247.

[29] Helzer JE, Robins LN, McEvoy L. Post-traumatic stress disorder in the general population. Findings of the epidemiologic catchment area survey. N Engl J Med 1987;317(26): 1630-1634.

[30] Breslau N. The epidemiology of posttraumatic stress disorder: what is the extent of the problem? J Clin Psychiatry 2001;62(17): 16-22.

[31] Breslau N. Epidemiologic studies of trauma, posttraumatic stress disorder, and other psychiatric disorders. Can J Psychiatry 2002;47(10): 923-929.

[32] Goenjian AK. A mental health relief programme in Armenia after the 1988 earthquake. Br J Psychiatry 1993;163: 230-239.

[33] Bakunts AG. Mental disorders among Armenian volunteers fighting in Karabakh. Bekhterev Rev Psychiatr Med Psychol 1994(2): 77-79.

[34] Goenjian AK, Najarian LM, Pynoos RS, Steinberg AM, Manoukian G, Tavosian A, Fairbanks LA. Posttraumatic stress disorder in elderly and younger adults after the 1988 earthquake in Armenia. Am J Psychiatry 1994;151: 895-901.

[35] Azarian A, Skriptchenko-Gregorian V. Children in natural disasters: an experience of the 1988 earthquake in Armenia. US: American Academy of Experts in Traumatic Stress Inc; 1998. http://www.aaets.org/article38.htm

[36] Goenjian AK, Steinberg AM, Najarian LM, Fairbanks LA, Tashjian M, Pynoos RS. Prospective study of posttraumatic stress, anxiety, and depressive reactions after earthquake and political violence. Am J Psychiatry 2000;157: 911-916.

[37] Goenjian AK, Pynoos RS, Steinberg AM, Endres D, Abraham K, Geffner ME, Fairbanks LA. Hypothalamic-pituitary-adrenal activity among Armenian adolescents with PTSD symptoms. J Traumatic Stress 2003;16(4): 319-323.

[38] Sukiasyan SH, Tadevosyan AS, Jeshmaridian SS, Manasyan NG. Stress and post stress disorders: personality and society. Yerevan: Asoghik Publishing House; 2003. 
[39] Sukiasyan SH, Tadevosyan MJ. Posttraumatic stress disorder: medical and social psychological problem in Armenia. Russ J Psychiatry 2010;5: 59-69.

[40] Karenian H, Livaditis M, Karenian S, Zafiriadis K, Bochtsou V, Xenitidis K. Collective trauma transmission and traumatic reactions among descendants of Armenian refugees. Int J Soc Psychiatry 2011;57(4): 327-337.

[41] Sapolsky RM. Atrophy of the hippocampus in posttraumatic stress disorder: how and when? Hippocampus 2001;11: 90-91.

[42] Shin LM, Shin PS, Heckers S, Krangel TS, Mackli ML, Orr SP. Hippocampal function in posttraumatic stress disorder. Hippocampus 2004;14: 292-300.

[43] Karl A, Schaefer M, Malta LS, Dorfel D, Rohleder N, Werner A. A meta-analysis of structural brain abnormalities in PTSD. Neurosci Biobehav Rev 2006;30(7): 1004-1031.

[44] Heim C, Ehlert U, Hellhammer DH. The potential role of hypocortisolism in the pathophysiology of stress-related bodily disorders. Psychoneuroendocrinology 2000;25: 1-35.

[45] Gill JM, Vythilingam M, Page GG. Low cortisol, high DHEA, and high levels of stimulated TNF- $\alpha$, and IL-6 in women with PTSD. J Trauma Stress 2008;21(6): 530-539.

[46] Tucker P, Ruwe WD, Masters B. Neuroimmune and cortisol changes in selective serotonin reuptake inhibitor and placebo treatment of chronic posttraumatic stress disorder. Biol Psychiatry 2004;56: 121-128.

[47] Carpenter LL, Tyrka AR, McDougle CJ, Malison RT, Owens MJ, Nemeroff CB, Price LH. Cerebrospinal fluid corticotropin-releasing factor and perceived early-life stress in depressed patients and healthy control subjects. Neuropsychopharmacology 2004;29(4): 777-784.

[48] De Kloet CS, Vermetten E, Bikker A, Meulman E, Geuze E, Kavelaars A, Westenberg HG, Heijnen CJ. Leukocyte glucocorticoid receptor expression and immunoregulation in veterans with and without post-traumatic stress disorder. Mol Psychiatry 2007;12(5):443-453.

[49] Geracioti TD. Plasma and cerebrospinal fluid interleukin-6 concentrations in posttraumatic stress disorder. Neuroimmunomodulation 2001;9: 209-217.

[50] Heim C, Nemeroff CB. Neurobiology of posttraumatic stress disorder. CNS Spectr 2009;14(1): 13-24.

[51] Yehuda R, Southwick S, Giller EL, Ma X, Mason JW. Urinary catecholamine excretion and severity of PTSD symptoms in Vietnam combat veterans. J Nerv Ment Dis 1992;180(5): 321-325.

[52] Hamner MB, Diamond BI. Elevated plasma dopamine in posttraumatic stress disorder: a preliminary report. Biol Psychiatry 1993;33(4): 304-306. 
[53] Glover DA, Powers MB, Bergman L, Smits JAJ, Telch MJ, Stube M. Urinary dopamine and turn bias in traumatized women with and without PTSD symptoms. Behavioural Brain Research 2003;144: 137-141.

[54] Pivac N, Kozarić-Kovačić D. Neurobiology of PTSD. In: Begec S. (ed.) The integration and management of traumatized people after terrorist attack. Amsterdam: IOS Press; 2007. p41-62.

[55] Comings DE, Muhleman D, Gysin R. Dopamine D2 receptor (DRD2) gene and susceptibility to posttraumatic stress disorder: a study and replication. Biol Psychiatry 1996;40: 368-372.

[56] Segman RH, Cooper-Kazaz R, Macciardi F, Goltser T, Halfon Y, Dobroborski T, Shalev AY. Association between the dopamine transporter gene and posttraumatic stress disorder. Mol Psychiatry 2002;7: 903-907.

[57] Dragan WL, Oniszczenko W. The association between dopamine D4 receptor exon III polymorphism and intensity of PTSD symptoms among flood survivors. Anxiety Stress Coping 2009;22: 483-495.

[58] Feusner J, Ritchie T, Lawford B, Young RM, Kann B, Noble EP. GABA(A) receptor beta 3 subunit gene and psychiatric morbidity in a post-traumatic stress disorder population. Psychiatry Res 2001;104(2): 109-117.

[59] Lesch KP, Bengel D, Heils A, Sabol SZ, Greenberg BD, Petri S, Benjamin J, Muller CR, Hamer DH, Murphy DL. Association of anxiety-related traits with a polymorphism in the serotonin transporter gene regulatory region. Science 1996;274(5292): 1527-1531.

[60] Kilpatrick DG, Koenen KC, Ruggiero KJ, Acierno R, Galea S, Resnick HS, Roitzsch J, Boyle J, Gelernter J. The serotonin transporter genotype and social support and moderation of posttraumatic stress disorder and depression in hurricane exposed adults. Am J Psychiatry 2007;164: 1693-1699.

[61] Eley TC, Sugden K, Corsico A, Gregory AM, Sham P. Gene-environment interaction analysis of serotonin system markers with adolescent depression. Mol Psychiatry 2004;9(10): 908-915.

[62] Kendler KS, Kuhn JW, Vittum J, Prescott CA, Riley B. The interaction of stressful life events and a serotonin transporter polymorphism in the prediction of episodes of major depression: a replicatio. Arch Gen Psychiatry 2005;62(5): 529-535.

[63] Grabe HJ, Spitzer C, Schwahn C, Marcinek A, Frahnow A, Barnow S, Lucht M, Freyberger HJ, John U, Wallaschofski H, Völzke H, Rosskopf D. Serotonin transporter gene (SLC6A4) promoter polymorphisms and the susceptibility to posttraumatic stress disorder in the general population. Am J Psychiatry 2009; 166: 926-933.

[64] Goenjian AK, Bailey JN, Walling DP, Steinberg AM, Schmidt D, Dandekar U, NobleEP. Association of TPH1, TPH2, and 5HTTLPR with PTSD and depressive symptoms. J Affect Disord 2012 [Epub ahead of print]. 
[65] Voisey J, Swagell CD, Hughes IP, Morris CP, Van Daal A, Noble EP, Kann B, Heslop KA, Young RM, Lawford BR. The DRD2 gene 957C > T polymorphism is associated with posttraumatic stress disorder in war veterans. Depress Anxiety 2009;6(1): 28-33.

[66] Drury SS, Theall KP, Keats BJ, Scheeringa M. The role of the dopamine transporter (DAT) in the development of PTSD in preschool children. J Trauma Stress 2009;22: 534-539.

[67] Lee HJ, Lee MS, Kang RH, Kim H, Kim SD, Kee BS, Kim YH, Kim YK, Kim JB, Yeon BK, Oh KS, Oh BH, Yoon JS, Lee C, Jung HY, Chee IS, Paik IH. Influence of the serotonin transporter promoter gene polymorphism on susceptibility to posttraumatic stress disorder. Depress Anxiety 2005;21: 135-139.

[68] Lee H, Kwak S, Paik J, Kang R, Lee M. Association between serotonin 2A receptor gene polymorphism and posttraumatic stress disorder. Psychiatry Investig 2007;4: 104-108.

[69] Thakur GA, Joober R, Brunet A. Development and persistence of posttraumatic stress disorder and the 5-HTTLPR polymorphism. J Trauma Stress 2009;22: 240-243.

[70] Xie P, Kranzler HR, Poling J, Stein MB, Anton RF, Brady K, Weiss RD, Farrer L, Gelernter J. Interactive effect of stressful life events and the serotonin transporter 5HTTLPR genotype on posttraumatic stress disorder diagnosis in 2 independent populations. Arch Gen Psychiatry 2009;66: 1201-1209.

[71] Sayin A, Kucukyildirim S, Akar T, Bakkaloglu Z, Demircan A, Kurtoglu G, Demirel $B$, Candansayar S, Mergen $\mathrm{H}$. A prospective study of serotonin transporter gene promoter (5-HTT gene linked polymorphic region) and intron 2 (variable number of tandem repeats) polymorphisms as predictors of trauma response to mild physical injury. DNA Cell Biol 2010;29: 71-77.

[72] Zhang H, Ozbay F, Lappalainen J, Kranzler HR, van Dyck CH, Charney DS, Price LH, Southwick S, Yang BZ, Rasmussen A, Gelernter J. Brain derived neurotrophic factor (BDNF) gene variants and Alzheimer's disease, affective disorders, posttraumatic stress disorder, schizophrenia, and substance dependence. Am J Med Genet B Neuropsychiatr Genet 2006;141: 387-393.

[73] Lappalainen J, Kranzler HR, Malison R, Price LH, Van Dyck C, Rosenheck RA, Cramer J, Southwick S, Charney D, Krystal J, Gelernter J. A functional neuropeptide Y Leu7Pro polymorphism associated with alcohol dependence in a large population sample from the United States. Arch Gen Psychiatry 2002;59: 825-831.

[74] Bachmann AW, Sedgley TL, Jackson RV. Glucocorticoid receptor polymorphisms and post-traumatic stress disorder. Psychoneuroendocrinology 2005;30: 297-306.

[75] Mustapic M, Pivac N, Kozaric-Kovacic D, Dezeljin M, Cubells JF, Mück-Seler D. Dopamine beta-hydroxylase (DBH) activity and -1021C/T polymorphism of DBH gene in combat-related post-traumatic stress disorder. Am J Med Genet Neuropsychiatr Genet 2007;144B(8): 1087-1089. 
[76] Lu AT, Ogdie MN, Jarvelin MR, Moilanen IK, Loo SK, McCracken JT, McGough JJ, Yang MH, Peltonen L, Nelson SF, Cantor RM, Smalley SL. Association of the cannabinoid receptor gene (CNR1) with ADHD and posttraumatic stress disorder. Am J Med Gene Neuropsychiatr Genet 2008;147B: 1488-1494.

[77] Nelson EC, Agrawal A, Pergadia ML, Lynskey MT, Todorov AA, Wang JC, Todd RD, Martin NG, Heath AC, Goate AM, Montgomery GW, Madden PA. Association of childhood trauma exposure and GABRA2 polymorphisms with risk of posttraumatic stress disorder in adults. Mol Psychiatry 2009;14: 234-235.

[78] Kolassa IT, Kolassa S, Ertl V, Papassotiropoulos A, De Quervain DJ. The risk of posttraumatic stress disorder after trauma depends on traumatic load and the catechol-omethyltransferase Val(158)Met polymorphism. Biol Psychiatry 2010;67: 304-308.

[79] Miller AH. Neuroendocrine and immune system interactions in stress and depression. Psychiatr Clin North Am 1998;21: 443-463.

[80] Wilson SN, Van der Kolk B, Burbridge J, Fisler R, Kradin R. Phenotype of blood lymphocytes in PTSD suggests chronic immune activation. Psychosomatics 1999;40(3): 222-225.

[81] Kawamura N, Kim Y, Asukai N. Suppression of cellular immunity in men with a past history of posttraumatic stress disorder. Am J Psych 2001;158: 484-486.

[82] Wong CM. Post-traumatic stress disorder: advances in psychoneuroimmunology. Psychiatr Clin North Am 2002;25(2): 369-383.

[83] Altemus M, Enhanced cellular immune response in women with PTSD related to childhood abuse. Am J Psych 2003;160: 1705-1707.

[84] Everson MP, Kotler S, Blackburn WD. PTSD and immune dysregulation in gulf war veterans. Med. Eval. Programs VA Gulf War Registry. 2005. https:// www.gulflink.osd.mil/medical.

[85] Segman RH, Shefi N, Goltser-Dubner T, Friedman N, Kaminski N, Shalev AY. Peripheral blood mononuclear cell gene expression profiles identify emergent posttraumatic stress disorder among trauma survivors. Mol. Psychiatry 2005;10: 500-513.

[86] Altemus M, Dhabhar FS, Yang R. Immune function in PTSD. Ann NY Acad Sci 2006;1071: 167-183.

[87] Spivak B, Shohat B, Mester R, Avraham S, Gil-Ad I, Bleich A, Valevski A, Weizman A. Elevated levels of serum interleukin-1 beta in combat-related posttraumatic stress disorder. Biol Psychiatry 1997;42(5): 345-348.

[88] Aurer A, Aurer-Kozelj J, Stavljenic-Rukavina A, Kalenic S, Ivic-Kardu M, Haban V. Infammatory mediators in saliva of patients with rapidly progressive periodontis during war stress induced incidence increase. Coll Antropol 1999;23: 117-124.

[89] Maes M, Lin AH., Delmeire L, Van Gastel A, Kenis G, De Jongh R, Bosmans E. Elevated serum interleukin-6 (IL-6) and IL-6 receptor concentrations in postraumatic 
stress disorder following accidental man-made traumatic events. Biol Psychiatry 1999;45(7): 833-839.

[90] Miller RJ, Sutherland AG, Hutchinson JD, Alexander DA. C-reactive protein and interleukin 6 receptor in post-traumatic stress disorder: a pilot study. Cytokine 2001;13: 253-255.

[91] Baker DG, Ekhator NN, Kasckow JW, Hill KK, Zoumakis E, Dashevsky BA, Chrousos GP, Geracioti TD. Plasma and cerebrospinal fluid interleukin-6 concentrations in posttraumatic stress disorder. Neuroimmunomodulation 2001;9(4): 209-217.

[92] Wessa M, Rohleder N. Endocrine and inflammatory alterations in post-traumatic stress disorder. Expert Rev Endocrinol Metab 2007;2(1): 91-122.

[93] von Känel R, Hepp U, Kraemer B, Traber R, Keel M, Mica L, Schnyder U. Evidence for low-grade systemic proinflammatory activity in patients with posttraumatic stress disorder. J Psychiatr Res 2007;41(9): 744-752.

[94] Gill JM, Saligan L, Woods S, Page G. PTSD is associated with an excess of inflammatory immune activities. Perspect Psychiatr Care 2009;45(4): 262-277.

[95] Spitzer C, Barnow S, Völzke H, Wallaschofski H, John U, Freyberger HJ, Löwe B, Grabe HJ. Association of posttraumatic stress disorder with low-grade elevation of C-reactive protein: Evidence from the general population. J Psychiatr Res 2010;44(1): $15-21$.

[96] Von Känel R, Begré S, Abbas ChC, Saner H, Gander ML, Schmid JP. Inflammatory biomarkers in patients with posttraumatic stress disorder caused by myocardial infarction and the role of depressive symptoms. Neuroimmunomodulation 2010;17(1): 39-46.

[97] Kawamura N, Kim Y, Asukai N. Suppression of cellular immunity in men with a past history of posttraumatic stress disorder. Am J Psych 2001;158: 484-486.

[98] Glover DA, Steele AC, Stuber ML, Fahey JL. Preliminary evidence for lymphocyte distribution differences at rest and after acute psychological stress in PTSD-symptomatic women. Brain Behav Immun 2005;19(3): 243-251.

[99] Ironson G, Wynings C, Schneiderman N, Baum A, Rodriguez M, Greenwood D, Benight C, Antoni M, LaPerriere A, Huang HS, Klimas N, Fletcher MA. Posttraumatic stress symptoms, intrusive thoughts, loss, and immune function after Hurricane Andrew. Psychosom Med 1997;59(2): 128-141.

[100] Vidović A, Gotovac K, Vilibić M, Sabioncello A, Jovanović T, Rabatić S, FolnegovićŠmalć V, Dekaris D. Repeated assessments of endocrine- and immune-related changes in posttraumatic stress disorder. Neuroimmunomodulation 2011;18(4): 199-211.

[101] Mosnaim AD, Wolf ME, Maturana P, Mosnaim G, Puente J, Kucuk O, Gilman-Sachs A. In vitro studies of natural killer cell activity in post traumatic stress disorder pa- 
tients. Response to methionine-enkephalin challenge. Immunopharmacology 1993;25(2): 107-116.

[102] Inoue-Sakurai C, Maruyama S, Morimoto K. Posttraumatic stress and lifestyles are associated with natural killer cell activity in victims of the Hanshin-Awaji earthquake in Japan. Prev Med 2000;31(5): 467-473.

[103] Gotovac K, Vidović A, Vukusić H, Krcmar T, Sabioncello A, Rabatić S, Dekaris D. Natural killer cell cytotoxicity and lymphocyte perforin expression in veterans with posttraumatic stress disorder. Prog Neuropsychopharmacol Biol Psychiatry 2010;34(4): 597-604.

[104] Skarpa I, Rubesa G, Moro L, Manestar D, Petrovecki M, Rukavina D. Changes of cytolytic cells and perforin expression in patients with posttraumatic stress disorder. Croat Med J 2001;42(5): 551-555.

[105] Delahanty DL, Dougall AL, Craig KJ, Jenkins FJ, Baum A. Chronic stress and natural killer cell activity after exposure to traumatic death. Psychosom Med 1997;59(5): 467-476.

[106] Laudenslager ML, Aasal R, Adler L, Berger CL, Montgomery PT, Sandberg E, Wahlberg LJ, Wilkins RT, Zweig L, Reite ML. Elevated cytotoxicity in combat veterans with long-term post-traumatic stress disorder: preliminary observations. Brain Behav Immun 1998;12(1): 74-79.

[107] Boscarino JA, Chang J. Higher abnormal leukocyte and lymphocyte counts 20 years after exposure to severe stress: research and clinical implications. Psychosom Med 1999;61(3): 378-386.

[108] Rohleder N, Joksimovic L, Wolf JM, Kirschbaum C. Hypocortisolism and increased glucocorticoid sensitivity of pro-Inflammatory cytokine production in Bosnian war refugees with posttraumatic stress disorder. Biol Psychiatry 2004;1(55):745-751.

[109] Grassi-Oliveira R, Brietzke E, Pezzi JC, Lopes RP, Teixeira AL, Bauer ME. Increased soluble tumor necrosis factor-alpha receptors in patients with major depressive disorder. Psychiatry Clin Neurosci 2009;63(2):202-208.

[110] Smith AK, Conneely KN, Kilaru V, Mercer KB, Weiss TE, Bradley B, Tang Y, Gillespie CF, Cubells JF, Ressler KJ. Differential immune system DNA methylation and cytokine regulation in post-traumatic stress disorder. Am J Med Genet B Neuropsychiatr Genet 2011;156(6): 700-708.

[111] Woods AB, Page GG, O'Campo P. The mediation effect of posttraumatic stress disorder symptoms on the relationship of intimate partner violence and IFN-gamma levels. Am J Community Psychol 2005;36: 159-175.

[112] First MB, Spitzer RL, Gibbon M, Williams JB. Structured clinical interview for the DSM-IV® axis I disorders (SCID-I), clinician version, user's guide. USA: Am Psych Press Inc; 1997. 
[113] Blake DD, Weathers FW, Nagy LM, Kaloupek DG, Gusman FD, Charney DS, Keane TM. The development of a clinician administered PTSD scale. J Trauma Stress 1995;8(1): 75-90.

[114] Hovhannisyan LP, Mkrtchyan GM, Sukiasian SH, Boyajyan AS. Classic and alternative complement cascades in post-traumatic stress disorder. Bull Exper Biol Medic 2009;148(6): 859-861.

[115] Hovhannisyan LP, Mkrtchyan GM, Boyajyan AS, Avetyan DG, Tadevosyan MY, Sukiasyan SH. Inflammatory markers in post-traumatic stress disorder. Cytokines \& Inflammation 2012;11(1): 42-45.

[116] Boscarino JA. Diseases among men 20 years after exposure to severe stress: implications for clinical research and medical care. Psychosom Med 1997;59: 605-614.

[117] Boscarino JA, Chang J. Electrocardiogram abnormalities among men with stress-related psychiatric disorders: implications for coronary heart disease and clinical research. Ann Behav Med 1999;21: 227-234.

[118] Weisberg RB, Bruce SE, Machan JT, Kessler RC, Culpepper L, Keller MB. Nonpsychiatric illness among primary care patieints with trauma histories and posttraumatic stress disorder. Psychiatr Serv 2002;53: 848-854.

[119] Kimerling R. An investigation of sex differences in non-psychiatric morbidity associated with posttraumatic stress disorder. J Am Med Womens Assoc 2004;59: 43-47.

[120] Boscarino JA. Posttraumatic stress disorder and physical illness: results from clinical and epidemiologic studies. Ann NY Acad Sci 2004;1032: 141-153.

[121] David D, Woodward C, Esquenazi J, Mellman TA. Comparison of comorbid physical illnesses among veterans with PTSD and veterans with alcohol dependence. Psychiatr Serv 2004;55: 82-85.

[122] Shemesh E, Yehuda R, Milo O, Dinur I, Rudnick A, Vered Z, Cotter G. Posttraumatic stress, nonadherence and adverse outcome in survivors of a myocardial infarction. Psychosom Med 2004;66: 521-526.

[123] Baker DG, Ekhator NN, Kasckow JW, Dashevsky B, Horn PS, Bednarik L, Gander ML, Von Känel R. Myocardial infarction and post-traumatic stress disorder: frequency, outcome, and atherosclerotic mechanisms. Eur J Cardiovasc Prev 2006;13: 165-172.

[124] Reichlin S. Neuroendocrine-immune interactions. N Engl J Med 1993;329: 1246-1253.

[125] Spangelo BL, Judd A, Call G, Zumwalt J, Gorospe WC. Role of the cytokines in the hypothalamic-pituitary-adrenal and gonadal axes. Neuroimmunomodulation 1995;2: 299-312.

[126] Haddad JJ, Saadé NE, Safieh-Garabedian B. Cytokines and neuro-immune-endocrine interactions: a role for the hypothalamic-pituitary-adrenal revolving axis. J Neuroimmunol 2002; 133(1-2): 1-19 
[127] Ransohoff RM, Benveniste EN. Cytokines and the CNS(second ed.) UK: CRC Press LLC; 2005.

[128] Faith RE, Murgo AJ, Good RA, Plotnikoff NP. Cytokines: stress and immunity (second ed.) UK: CRC Press LLC; 2006.

[129] Pace TW, Heim CM. A short review on the psychoneuroimmunology of posttraumatic stress disorder: from risk factors to medical comorbidities.Brain Behav Immun 2011;25(1): 6-13.

[130] O'Brien SM, Scully P, Scott LV, Dinan TG. Cytokine profiles in bipolar affective disorder: focus on acutely ill patients. J Affect Disord 2006;90(2-3): 263-267.

[131] Fan X, Goff DC, Henderson DC. Inflammation and schizophrenia. Expert Rev Neurother 2007;7(7): 789-796.

[132] Gardner A, Boles RG. Beyond the serotonin hypothesis: mitochondria, inflammation and neurodegeneration in major depression and affective spectrum disorders. Prog Neuropsychopharmacol Biol Psychiatry 2011;35(3): 730-743.

[133] Sim RB, Laich A. Serine proteases of the complement system. Biochem Soc Trans 2000;28: 545-550.

[134] Cole DS, Morgan BP. Beyond lysis: how complement influences cell fate. Clin Sci 2003; 104(5): 455-466.

[135] Nauta AJ, Roos A, Daha MR. A regulatory role for complement in innate immunity and autoimmunity. Int Arch Allergy Immunol 2004;134(4): 310-323.

[136] Sakamoto M, Fujisawa Y, Nishioka K. Physiologic role of the complement system in host defense, disease, and malnutrition. Nutrition 1998;14(4): 391-398.

[137] Volankis JE, Frank MM: The human complement system in health and disease. New York: Mircel Dekker Inc; 1998.

[138] Mollnes TE, Song W-C, Lambris JD: Complement in inflammatory tissue damage and disease. Trends Immunol Today 2002;23(2): 61-66.

[139] Morgan BP, Gasque P, Singhrao SK, Piddlesden SJ. The role of complement in disorders of the nervous system. Immunopharmacology 1997;38(1-2): 43-50.

[140] Yasojima K, Schwab C, McGeer EG, McGeer PL. Up-regulated production and activation of the complement system in Alzheimer's disease brain. Amer J Pathol 1999;154(3): 927-936.

[141] Gasque P, Neal JW, Singhrao SK, McGreal EP, Dean YD,Van BJ, Morgan BP. Roles of the complement system in human neurodegenerative disorders: pro-inflammatory and tissue remodeling activities. Mol Neurobiol 2002;25(1): 1-17.

[142] Francis K, Van Beek J, Canova C, Neal JW, Gasque P. Innate immunity and brain inflammation: the key role of complement. Expert Rev Mol Med 2003;5(15): 1-19. 
[143] Van Beek J, Elward K, Gasque P. Activation of complement in the central nervous system: roles in neurodegeneration and neuroprotection. Ann N Y Acad Sci 2003;992: 56-71.

[144] Boyajyan A, Zakharyan R, Khoyetsyan A. Molecular and genetic indicators of aberrant immunity and apoptosis in schizophrenia. In: SumiyoshiT. (ed.) Schizophrenia Research: Recent Advances. USA: Nova Science Publishers Inc; 2012, p183-240.

[145] Maes M, Hendriks D, Van Gastel A, Demedts P, Wauters A, Neels H, Janca A, Scharpé S: Effects of psychological stress on serum immunoglobulin, complement, and acute phase protein concentrations in normal volunteers. Psychoneuroendocrinology 1997;22: 397-409.

[146] Burns V, Edwards K, Ring C, Drayson M, Carroll D. Complement cascade activation after an acute psychological stress task. Psychosomatic Medicine 2008;70: 387-396.

[147] Doods AW, Sim RB. Complement. A practical approach. Practical Approach series, Oxford: Oxford University Press Inc; 1997.

[148] Morgan P. Complement methods and protocols. Methods of Molecular Biology series. Totowa, New Jersey: Humana Press Inc; 2000.

[149] Hovhannisyan LP, Mkrtchyan GM, Boyajyan AS, Sukiasian SH. Immune complexes and complement classical cascade in posttraumatic stress disorder. Russ Biomed J 2008;9(2): 269-274. http://www.medline.ru/public/art/tom9/art023pdf.phtml

[150] Hovhannisyan L, Mkrtchyan G, Boyajyan A, Sukiasian S, Kalashyan A. Classical and alternative pathways complement activity and circulating immune complexes in patients with post-traumatic stress disorder. Scandinavian Journal of Immunology 2008;68(2): 204-205.

[151] Hovhannisyan LP, Mkrtchyan GM, Sukiasian SH, Ambardzumyan MK, Avetisyan GV, Boyajyan AS. Complement as a pathogenic factor in posttraumatic stress. Biol J Armenia 2009;61(1): 48-53.

[152] Hovhannisyan LP, Mkrtchyan GM, Sukiasyan SH, Boyajyan AS. Alterations in the complement cascade in post-traumatic stress disorder. Allergy, Asthma and Clinical Immunology 2010;6:3doi:10.1186/1710-1492-6-3.

[153] Gander ML, von Kanel R. Myocardial infarction and post-traumatic stress disorder: frequency, outcome, and atherosclerotic mechanisms. Eur J Cardiovasc Prev Rehabil 2006;13: 165-172.

[154] Schifferli JA, Ng YC, Peters DK. The role of complement and its receptor in the elimination of immune complexes. N Eng J Med 1986;315: 488-495.

[155] Moulds JM. Introduction to antibodies and complement. Transfus Apher Sci 2009;40(3): 185-188. 
[156] Ng YC, Schifferli JA, Walport MJ. Immune complexes and erythrocyte CR1 (complement receptor type 1): effect of CR1 numbers on binding and release reactions. Clin Exp Immunol 1988;71: 481-485.

[157] Hebert LA. The clearance of immune complexes from the circulation of man and other primates. Am J Kidney Dis 1991;17:352-361.

[158] Thornton BP, Vĕtvicka V, Ross GD. Natural antibody and complement-mediated antigen processing and presentation by B lymphocytes. J Immunol 1994;152(4): 1727-1737.

[159] Theofilopoulos AN. Evaluation and clinical significance of circulating immune complexes. Prog Clin Immunol 1980;4: 63-106.

[160] McDougal JS, McDuffie FC. Immune complexes in man: detection and clinical significance. Adv Clin Chem 1985;24: 1-60.

[161] Konstantinova N.A. Immune complexes and tissue damage. Moscow: Medicine; 1996.

[162] Shmagel KV, Chereshnev VA. Molecular bases of immune complex pathology. Biochemistry (Mosc) 2009;74(5): 469-479.

[163] Burut DF, Karim Y, Ferns GA. The role of immune complexes in atherogenesis. Angiology 2010;61(7): 679-689.

[164] Theofilopoulos AN, Dixon FJ. Immune complexes in human diseases. Am J Pathol 1980, 100(2): 529-594.

[165] Hovsepyan M, Boyajyan A, Aivazyan V, Mayilyan K, Guevorkyan A, Mamikonyan A. Concentration of circulating immune complexes and dopamine-hydroxylase activity in the blood of patients with diabetes mellitus type 1 at the late stages of the disease progression. Diabetes Mellitus (Mosc.) 2002;17(4): 44-45.

[166] Ovsepyan MR, Boyadjyan AS, Mamikonyan AA, Gevorkyan AA. Circulating immune complexes at the late stages of diabetes mellitus. Immunology (Mosc) 2004;25: 375

[167] Tarnacka B, Gromadzka G, Czlonkowska A. Increased circulating immune complexes in acute stroke: the triggering role of Chlamydia pneumoniae and cytomegalovirus. Stroke 2002;33(4): 936-940.

[168] Arakelian A, Boiadzhian A, Pogosian A, Bakunts G, Sil'vanian G, Egiian L. Circulating immune complexes in ischemic and hemorrhagic strokes. Zh Nevrol Psikhiatr Im S. S. Korsakova 2003;8: 44-47.

[169] Boiadzhian AS, Arakelova EA, Arakelian AA, Avetisian GV, Aivazian VA, Manucharian GG, Mkrtchian GM, Sim RB, Willis AK. Circulating immune complexes in families with positive history of ischemic stroke. Zh Nevrol Psikhiatr Im S. S. Korsakova 2007;21: 43-46. 
[170] Hovhannisyan LP. Circulating immune complexes as possible inflammatory markers in posttraumatic stress disorder. Med Sci Armenia 2010;50(4): 69-75.

[171] Grunnet LG, Aikin R, Tonnesen MF, Paraskevas S, Blaabjerg L, Størling J, Rosenberg L, Billestrup N, Maysinger D, Mandrup-Poulsen T. Proinflammatory cytokines activate the intrinsic apoptotic pathway in beta-cells. Diabetes 2009;58(8): 1807-1815.

[172] Haanen C, Vermes I. Apoptosis and inflammation. Mediators of Inflammation 1995;4(1): 5-15.

[173] Savill J. Apoptosis in resolution of inflammation. J Leukocyte Biol 1997;61: 375-380.

[174] Chae JJ, Komarow HD, Cheng J, Wood G, Raben N, Liu PP, Kastner DL. Targeted disruption of pyrin, the FMF protein, causes heightened sensitivity to endotoxin and a defect in macrophage apoptosis. Mol Cell 2003;11(3):591-604.

[175] Fantuzzi G. Adipose tissue, adipokines, and inflammation. J Allergy Clin Immunol 2005;115(5): 911-919.

[176] Parsey MV, Kaneko D, Shenkar R, Abraham E. Neutrophil apoptosis in the lung after hemorrhage or endotoxemia: apoptosis and migration are independent of interleukin-1 $\beta$. Chest 1999;116: 67S-68S

[177] Jimenez MF, Watson RW, Parodo J, Evans D, Foster D, Steinberg M, Rotstein OD, Marshall JC. Dysregulated expression of neutrophil apoptosis in the systemic inflammatory response syndrome. Arch Surg 1997;132: 1263-1269.

[178] Li Z, Sheng M. Caspases in synaptic plasticity. Mol. Brain 2012;14(5): 15.

[179] Chan SL, Mattson MP. Caspase and calpain substrates: roles in synaptic plasticity and cell death. J Neurosci Res 1999;58: 167-190.

[180] Gilman CP, Mattson MP. Do apoptotic mechanisms regulate synaptic plasticity and growth-cone motility? Neuromolecular Med 2002;2(2): 197-214.

[181] Mahan AL, Ressler KJ. Fear conditioning, synapticplasticity and the amygdala: implications for posttraumatic stress disorder. Trends Neurosci 2012;35(1): 24-36.

[182] Duman RS. Pathophysiology of depression: the concept of synaptic plasticity. Eur Psychiatry 2002;17(3): 306-310.

[183] Hart J, Kimbrell T, Fauver P, Cherry BJ, Pitcock J, Booe LQ, Tillman G, Freeman TW. Cognitive dysfunctions associated with PTSD: evidence from World War II prisoners of war. J Neuropsychiatry Clin Neurosci 2008;20: 309-316.

[184] Moore SA. Cognitive abnormalities in posttraumatic stress disorder. Curr Opin Psychiatry 2009; 22(1): 19-24.

[185] Boersma HH, Kietselaer BL, Stolk LM, Bennaghmouch A, Hofstra L, Narula J, Heidendal GA, Reutelingsperger CP. Past, present, and future of Annexin A5: from protein discovery to clinical applications. JNM 2005;46(12): 2035-2050. 
[186] Brose N. Altered complexin expression in psychiatric and neurological disorders: cause or consequence? Mol Cells 2008;25(1): 7-19. 
